\title{
Estimasi Fungsi Survival dan Fungsi Hazard Kumulatif Pada Data Survival Pederita Multiple Myeloma Serta Faktor-faktor yang Mempengaruhi Waktu Survivalnya
}

\author{
Toto Hermawan, Dwi Nurrohmah, Ismi Fathul Jannah \\ Fakultas KeguruanIlmu Pendidikan, Universitas Cokroaminoto Yogyakarta \\ totohermawan@ucy.ac.id
}

\begin{abstract}
Abstrak
Multiple Myeloma adalah suatu penyakit menular dengan karakteristik oleh akumulasi dari sel plasma abnormal, tipe sel darah putih, pada sumsum tulang. Tujuan utama dari analisa data ini adalah untuk menyelidiki pengaruh factor resiko Bun, Ca, Pcells dan Protein pada waktu survival pasien multiple myeloma.dari diagnose hingga kematian.Dalam anaisis data survival, variable random $T$ yang diamati adalah waktu yang diperlukan untuk mencapai keberhasilan. Untuk menjelaskan suatu variable random, dapat digunakan fungsi sebaran kumulatif atau fungsi kepadatan peluangnya. Dalam analisis survival, fungsi dari variable random yang menjadi penting adalah fungsi survival dan fungsi hazard yang dapat diturunkan menggunakan fungsi sebaran kumulatif atau fungsi kepadatan peluang.Secara umum, sulit untuk menentukan fungsi survival atau fungsi hazard dari sekelompok populasi secara pasti. Walaupun demikian, fungsi survival atau fungsi hazard tetap dapat didekati dengan metode estimasi tertentu. Metode Kaplan-Meier dapat digunakan untuk mencari estimator dari fungsi survival suatu populasi. Sedangkan untuk menemukan estimastor fungsi hazard kumuatif dapat digunakan metode Nelson-Aalen. Dari variable-variabel yang dipelajari ternyata yang memberikan pengaruh yang paling signifikan adalah variable Bun yaitu kadar blood urea nitrogen baik menggunakan distribusi eksponensial maupun weibull. Namun dengan menggunakan distribusi weibull, adanya Protein Bence Jones di dalam air seni juga memberikan pengaruh yang cukupnyata
\end{abstract}

Kata Kunci : Multiple Myeloma,fungsi hazard, Metode Kaplan-Meier, Metode Nelson-Aalen

\section{PEDAHULUAN}

Multiple Myeloma adalah suatu penyakit menular dengan karakteristik oleh akumulasi dari sel plasma abnormal, tipe sel darah putih, pada sumsum tulang. Perkembangbiakan sel plasma abnormal didalam tulang menyebabkan sakit dan merusak jaringan tulang. Pasien multiple myeloma juga mengalami anemia, pendarahan (haemorrhages), kelemahan dan infeksi/peradangan kumat. 
Dalam analisis data ini hal yang ingin dicapai adalah menentukan estimasi fungsi survival dan fungsi harazd kumulatif pada data survival pasien Multiple Myeloma. Selain itu juga akan diselidiki faktor-faktor apa saja yang memberikan pengaruh terhadap waktu survival pasien Multiple Myeloma.

\section{METODE PENELITIAN}

Data survival adalah lama waktu sampai suatu peristiwa terjadi atau data antar kejadian (time-to-event data). Dalam beberapa bidang ilmu digunakan istilah durasi (durational data) misalnya di bidang ekonomi. Di bidang ilmu perekayasaan sering disebut data waktu kerusakan (failure time data). Dalam ilmu sosial digunakan istilah event history data. Istilah data survival sendiri banyak digunakan dalam bidang ilmu kesehatan, epidemiologi, demografi dan aktuaria. Untuk memperoleh data survival, diperlukan tiga komponen yang harus terdefinisikan dengan jelas terkait fenomena yang menjadi perhatian, yaitu:

1. Definisi event/peristiwa yang menjadi perhatian.

2. Titik asal (origin) yang digunakan untuk mengukur lama waktu sampai suatu event terjadi.

3. Unit pengukuran yang digunakan.

Estimasi Fungsi Survival Estimator standar dalam fungsi survival dikemukakan oleh Kaplan dan Meier pada tahun 1958, yang dinamakan estimator Product-Limit.

$$
\hat{S}(x)= \begin{cases}1 & , x<x_{i} \\ \prod_{x_{i} \leq x}\left[1-\frac{d_{i}}{Y_{i}}\right] & , x_{i} \leq x\end{cases}
$$

dengan di adalah banyaknya event dan Yi adalah banyaknya individu yang beresiko (number at risk) Sedangkan variansi dari Penaksir Product Limit adalah:

$$
\hat{\sigma}_{S}^{2}(x)=\hat{V}[\hat{S}(x)]=\hat{S}(x)^{2} \sum_{x_{i} \leq x} \frac{d_{i}}{Y_{i}\left(Y_{i}-d_{i}\right)}
$$

Estimator lain dari hazard kumulatif rata rata yang mempunyai ukuran sampel kecil lebih baik daripada penaksir yang berdasarkan penaksir Product-Limit, pertama kali dikemukakan oleh Nelson pada tahun 1972 dalam konteks reliabiliti kemudian dikemukakan 
kembali oleh Aalen pada tahun 1978 Fungsi hazard kumulatif berdasarkan estimator NelsonAalen didefinisikan Estimator untuk fungsi hazard kumulatif Nelson-Aalen Estimator

$$
\hat{H}(t)= \begin{cases}0 & \text { jika } t<t_{1} \\ \sum_{t_{i} \leq t} \frac{d_{i}}{Y_{i}} & \text { jika } t_{i} \leq t\end{cases}
$$

Sedangkan variansi dari Penaksir

$$
\operatorname{var}(\hat{H}(t))=\sum_{t_{i} \leq t} \frac{d_{i}}{Y_{i}^{2}}
$$

Data diperoleh dari buku Modelling Survival Data in Medical Research (Second Edition) yang ditulis Oleh D. Collett. Variabel respon yang diamati adalah waktu dalam bulan, Tujuan utama dari analisa data ini adalah untuk menyelidiki pengaruh faktor resiko Bun, Ca, Pcells dan Protein pada waktu survival pasien multiple myeloma.dari diagnosa hingga kematian. Adapun data lengkap tersaji dalam table berikut:

Tabel. Waktu Survival Pasien dalam Studi Multiple Myeloma

\begin{tabular}{|c|c|c|c|c|c|c|c|c|c|}
\hline $\begin{array}{c}\text { No. } \\
\text { Pasien }\end{array}$ & $\begin{array}{c}\text { Waktu } \\
\text { Survival }\end{array}$ & Status & Usia & $\begin{array}{c}\text { Jenis } \\
\text { Kelamin }\end{array}$ & Bun & $\mathrm{Ca}$ & $\mathrm{Hb}$ & Pcells & Protein \\
\hline 1 & 13 & 1 & 66 & 1 & 25 & 10 & 14.6 & 18 & 1 \\
\hline 2 & 52 & 0 & 66 & 1 & 13 & 11 & 12 & 100 & 0 \\
\hline 3 & 6 & 1 & 53 & 2 & 15 & 13 & 11.4 & 33 & 1 \\
\hline 4 & 40 & 1 & 69 & 1 & 10 & 10 & 10.2 & 30 & 1 \\
\hline 5 & 10 & 1 & 65 & 1 & 20 & 10 & 13.2 & 66 & 0 \\
\hline 6 & 7 & 0 & 57 & 2 & 12 & 8 & 9.9 & 45 & 0 \\
\hline 7 & 66 & 1 & 52 & 1 & 21 & 10 & 12.8 & 11 & 1 \\
\hline 8 & 10 & 0 & 60 & 1 & 41 & 9 & 14 & 70 & 1 \\
\hline 9 & 10 & 1 & 70 & 1 & 37 & 12 & 7.5 & 47 & 0 \\
\hline 10 & 14 & 1 & 70 & 1 & 40 & 11 & 10.6 & 27 & 0 \\
\hline 11 & 16 & 1 & 68 & 1 & 39 & 10 & 11.2 & 41 & 0 \\
\hline 12 & 4 & 1 & 50 & 2 & 172 & 9 & 10.1 & 46 & 1 \\
\hline 13 & 65 & 1 & 59 & 1 & 28 & 9 & 6.6 & 66 & 0 \\
\hline 14 & 5 & 1 & 60 & 1 & 13 & 10 & 9.7 & 25 & 0 \\
\hline 15 & 11 & 0 & 66 & 2 & 25 & 9 & 8.8 & 23 & 0 \\
\hline 16 & 10 & 1 & 51 & 2 & 12 & 9 & 9.6 & 80 & 0 \\
\hline 17 & 15 & 0 & 55 & 1 & 14 & 9 & 13 & 8 & 0 \\
\hline 18 & 5 & 1 & 67 & 2 & 26 & 8 & 10.4 & 49 & 0 \\
\hline 19 & 76 & 0 & 60 & 1 & 12 & 12 & 14 & 9 & 0 \\
\hline 20 & 56 & 0 & 66 & 1 & 18 & 11 & 12.5 & 90 & 0 \\
\hline 21 & 88 & 1 & 63 & 1 & 21 & 9 & 14 & 42 & 1 \\
\hline 22 & 24 & 1 & 67 & 1 & 10 & 10 & 12.4 & 44 & 0 \\
\hline 23 & 51 & 1 & 60 & 2 & 10 & 10 & 10.1 & 45 & 1 \\
\hline 24 & 4 & 1 & 74 & 1 & 48 & 9 & 6.5 & 54 & 0 \\
\hline
\end{tabular}




\begin{tabular}{|c|c|c|c|c|c|c|c|c|c|}
\hline 25 & 40 & 0 & 72 & 1 & 57 & 9 & 12.8 & 28 & 1 \\
\hline 26 & 8 & 1 & 55 & 1 & 53 & 12 & 8.2 & 55 & 0 \\
\hline 27 & 18 & 1 & 51 & 1 & 12 & 15 & 14.4 & 100 & 0 \\
\hline 28 & 5 & 1 & 70 & 2 & 130 & 8 & 10.2 & 23 & 0 \\
\hline 29 & 16 & 1 & 53 & 1 & 17 & 9 & 10 & 28 & 0 \\
\hline 30 & 50 & 1 & 74 & 1 & 37 & 13 & 7.7 & 11 & 1 \\
\hline 31 & 40 & 1 & 70 & 2 & 14 & 9 & 5 & 22 & 0 \\
\hline 32 & 1 & 1 & 67 & 1 & 165 & 10 & 9.4 & 90 & 0 \\
\hline 33 & 36 & 1 & 63 & 1 & 40 & 9 & 11 & 16 & 1 \\
\hline 34 & 5 & 1 & 77 & 1 & 23 & 8 & 9 & 29 & 0 \\
\hline 35 & 10 & 1 & 61 & 1 & 13 & 10 & 14 & 19 & 0 \\
\hline 36 & 91 & 1 & 58 & 2 & 27 & 11 & 11 & 26 & 1 \\
\hline 37 & 18 & 0 & 69 & 2 & 21 & 10 & 10.8 & 33 & 0 \\
\hline 38 & 1 & 1 & 57 & 1 & 20 & 9 & 5.1 & 100 & 1 \\
\hline 39 & 18 & 0 & 59 & 2 & 21 & 10 & 13 & 100 & 0 \\
\hline 40 & 6 & 1 & 61 & 2 & 11 & 10 & 5.1 & 100 & 0 \\
\hline 41 & 1 & 1 & 75 & 1 & 56 & 12 & 11.3 & 18 & 0 \\
\hline 42 & 23 & 1 & 56 & 2 & 20 & 9 & 14.6 & 3 & 0 \\
\hline 43 & 15 & 1 & 62 & 2 & 21 & 10 & 8.8 & 5 & 0 \\
\hline 44 & 18 & 1 & 60 & 2 & 18 & 9 & 7.5 & 85 & 1 \\
\hline 45 & 12 & 0 & 71 & 2 & 46 & 9 & 4.9 & 62 & 0 \\
\hline 46 & 12 & 1 & 60 & 2 & 6 & 10 & 5.5 & 25 & 0 \\
\hline 47 & 17 & 1 & 65 & 2 & 28 & 8 & 7.5 & 8 & 0 \\
\hline 48 & 3 & 0 & 59 & 1 & 90 & 10 & 10.2 & 6 & 1 \\
\hline & & & & & & & & \\
\hline
\end{tabular}

Jumlah pasien yang diamati adalah sebanyak 48 pasien, semua berusia diantara 50 dan 80 tahun. Sebagian pasien masih hidup setelah pengamatan selesai dilaksanakan sehingga menyebabkan adanya data (waktu survival) yang tersensor kanan. Pengkodean status survival $\left(\delta_{i}\right)$ dari individu dalam tabel sedemikian rupa sehingga 0 menotasikan pengamatan tersensor kanan dan 1 menotasikan kejadian, dalam hal ini yaitu kematian dari multiple myeloma.

Pada saat mendiagnosa, nilai-nilai sejumlah variabel penjelas dicatat untuk setiap pasien. Variabel penjelas dalam data tersebut yaitu usia pasien dalam tahun, jenis kelamin ( 1 = laki-laki, 2 = perempuan), level of blood urea nitrogen (Bun), serum kalsium (Ca) dan Hemoglobin $(\mathrm{Hb})$, persen dari sel plasma di dalam sumsum tulang (Pcells) dan indikator variabel (Protein) menotasikan apakah terdapat protein Bence Jones atau tidak di dalam air seni (urine) $(0=$ tidak ada, $1=$ ada $)$.

\section{PEMBAHASAN}

Dalam anaisis data survival, variable random $T$ yang diamati adalah waktu yang diperlukan untuk mencapai keberhasilan. Untuk menjelaskan suatu variable random, dapat digunakan fungsi sebaran kumulatif atau fungsi kepadatan peluangnya. Dalam analisis survival, fungsi dari variable random yang menjadi penting adalah fungsi survival dan fungsi 
hazard yang dapat diturunkan menggunakan fungsi sebaran kumulatif atau fungsi kepadatan peluang.

Secara umum, sulit untuk menentukan fungsi survival atau fungsi hazard dari sekelompok populasi secara pasti. Walaupun demikian, fungsi survival atau fungsi hazard tetap dapat didekati dengan metode estimasi tertentu. Metode Kaplan-Meier dapat digunakan untuk mencari estimator dari fungsi survival suatu populasi. Sedangkan untuk menemukan estimastor fungsi hazard kumuatif dapat digunakan metode Nelson-Aalen.

Pertama, untuk dapat menjelaskan atau memberikan deskripsi terhadap Variabel Random T yaitu waktu kematian pasien Multi Myeloma, akan ditentukan estimator fungsi survivalnya dengan menggunakan Estimator Kaplan Meier. Dengan alasan kemudahannya, komputasi akan dilakukan menggunakan program $R$. Berikut ini adalah pembentukan atau pendefinisian variabel dalam program $\mathrm{R}$

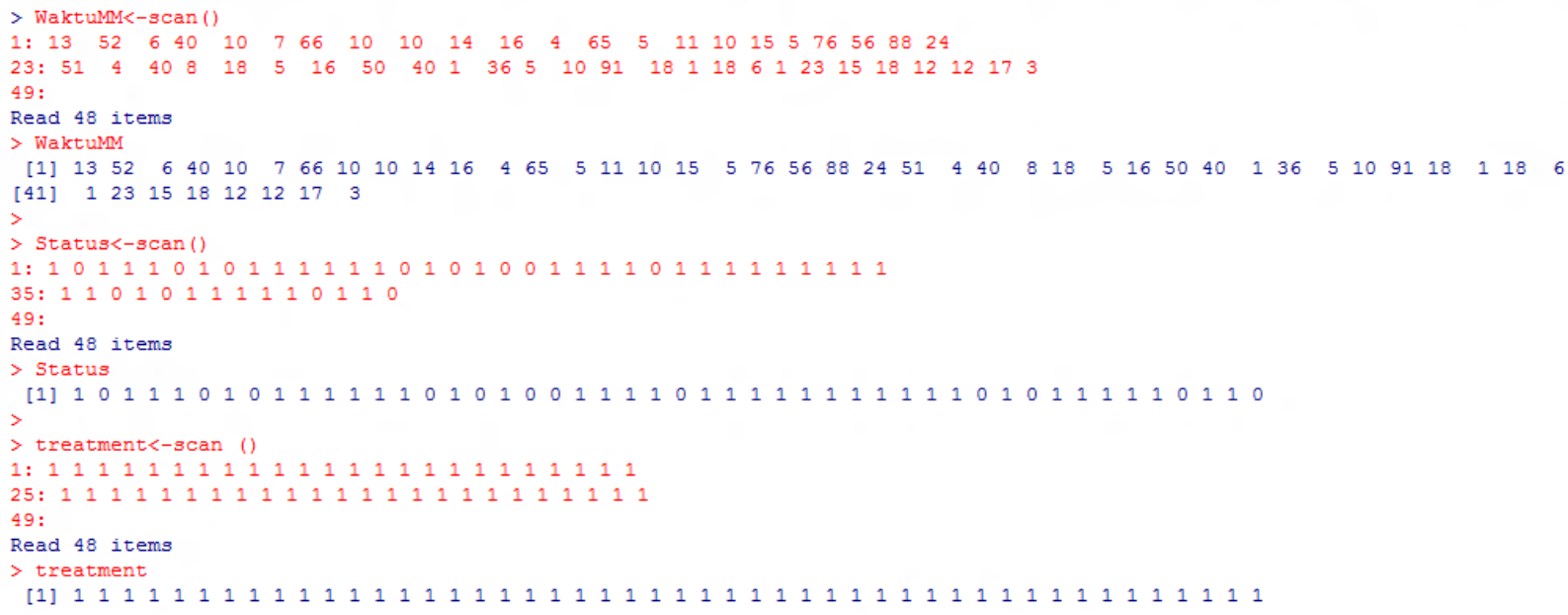

Fungsi Survival yang diperoleh dengan metode Kaplan-Meier ditunjukkan oleh output berikut:

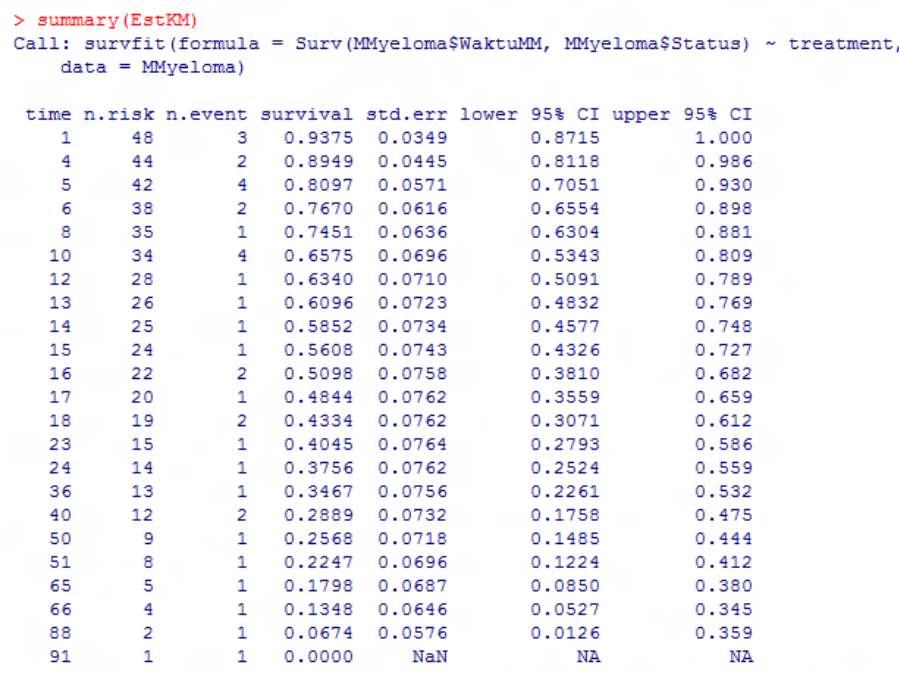


Berdasarkan teori, fungsi survival $S(t)$ menyatakan peluang satu individu hidup (survive) lebih lama daripada waktu $t$. Contohnya dari output di atas, kita dapat melihat bahwa peluang suatu individu dapat tetap bertahan setelah waktu $t=15$ bulan adalah 0.5608. Jika diamati lebih cermat maka akan terlihat bahwa $S(t)$ akan semakin menurun untuk $t$ yang semakin besar. Hal ini juga dapat dilihat melalui grafik dari fungsi survival berikut yang diperoleh dengan metode Kaplan-Meier.

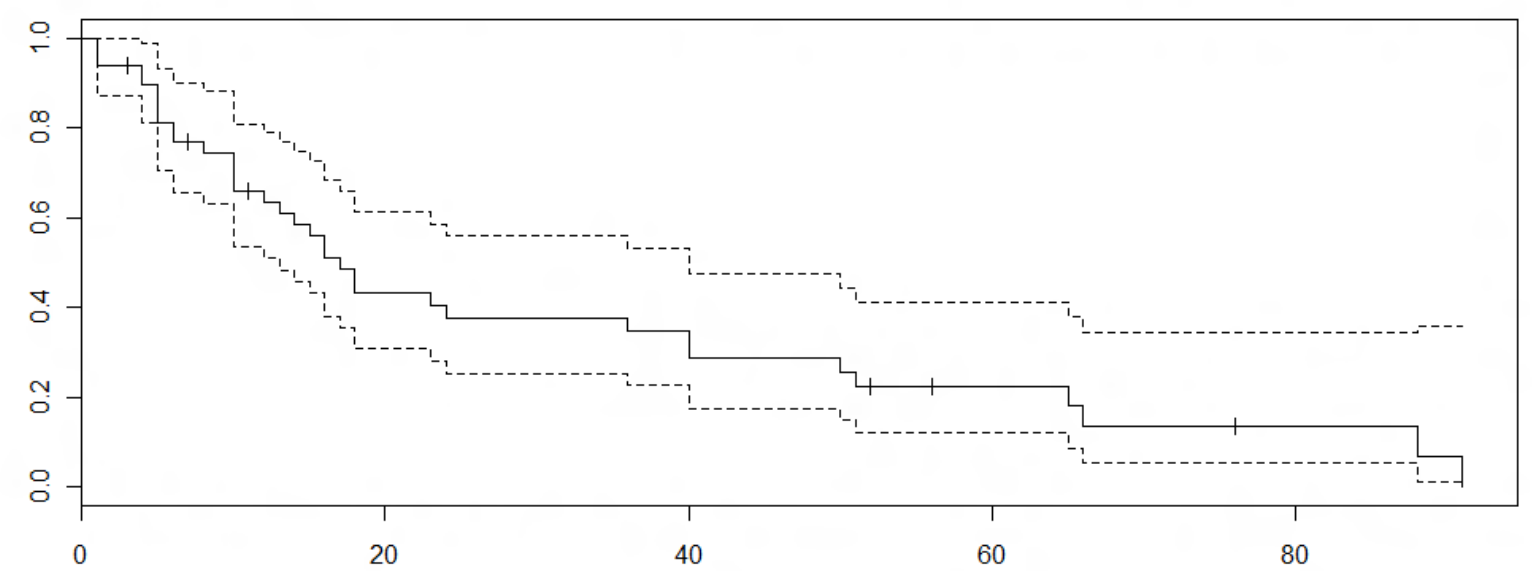

Untuk melihat fungsi hazard dari data survival Multiple Myeloma digunakan metode Nelson Aalen. Output di bawah ini adalah hasil komputasi menggunakan program R. Fungsi hazard kumulatif ini, $\widehat{H}(t)$, menyatakan tingkat (rate) terjadinya sebuah kematian dari pasien Multiple Myeloma pada sabelum atau saat $t$. Misalnya $\widehat{H}(5)=0.2031926$ menyatakan bahwa pada sebelum atau saat $t=5$ bulan tingkat terjadinya kematian adalah 0.2031926 . Sedangkan untuk mengetahui tingkat kematian pada saat $t=23$ bulan dapat ditentukan dengan $\widehat{h}(t=23)=\widehat{H}(23)-\widehat{H}(23)=0.8707241-0.8040574=0.0666667$

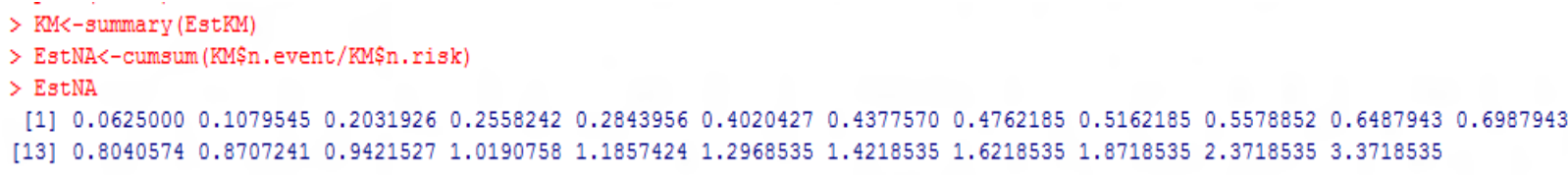

Akan menjadi menarik ketika data di atas dikelompokkan menjadi dua bagian berdasarkan kriteria tertentu. Masing-masing kelompok akan memiliki estimasi fungsi survival sendiri, sehingga keduanya dapat dibandingkan. 
Sekelompok data di atas dapat digolongkan menjadi dua bagian berdasarkan Jenis Kelamin. Dari masing-masing kelompok, yaitu kelompok laki-laki dan kelompok perempuan, dapat dibuat estimasi fungsi survivalnya yaitu dengan menggunakan Kapalan-Meier. Estimasi fungsi survival dengan menggunakan Kaplan-Meier untuk masing-masing kelompok diperlihatkan dalam output program R sebagai berikut:
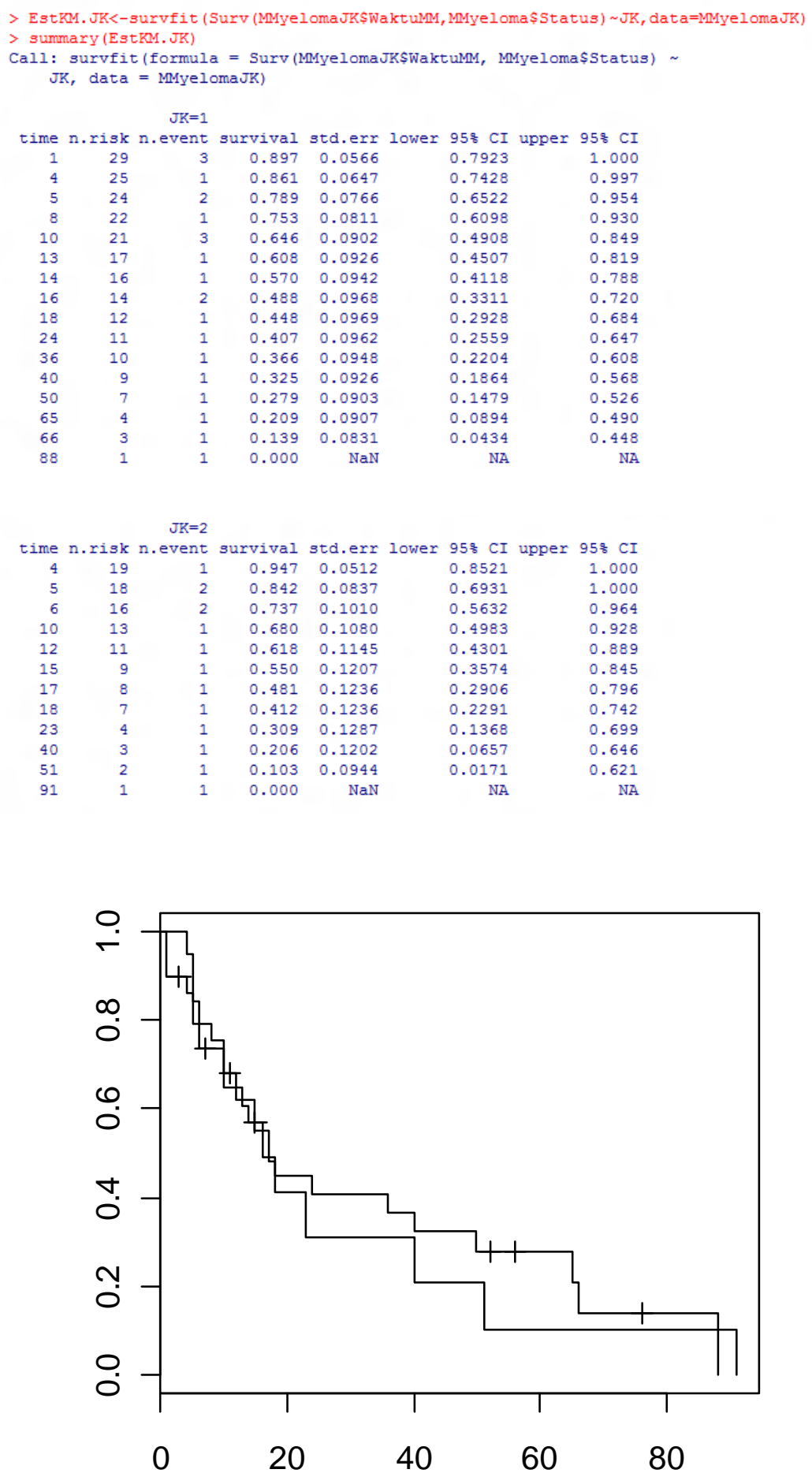
Jika dimisalkan $\hat{S}_{L}(t)$ dan $\hat{S}_{p}(t)$ masing-masing adalah estimasi fungsi survival dari kelompok laki-laki dan kelompok perempuan, maka secara matematika jelas dapat disimpulkan bahwa $\hat{S}_{L}(4)<\hat{S}_{p}(4)$ dan $\hat{S}_{L}(10)<\hat{S}_{p}(10)$. Dari grafik fungsi survival kelompok laki-laki dan kelompok perempuan juga dapat dilihat bahwa $\hat{S}_{L}(t)<\hat{S}_{p}(t)$ untuk hampir semua nilai $t$. Walaupun demikian, secara statistika kita belum dapat menyimpulkan bahwa kemampuan bertahan individu kelompok laki-laki lebih rendah dari pada kelompok perempuan. Untuk menghasilkan kesimpulan dari persoalan ini diperlukan sebuah uji statistika. Berkenaan dengan hal ini secara umum hipotesis yang akan diuji adalah

$$
\begin{aligned}
& H_{0} \text { : Fungsi Survival antara kedua kelompok sama, } \hat{S}_{L}(t)=\hat{S}_{p}(t) \\
& H_{1} \text { : Fungsi Survival antara kedua kelompok berbeda, } \hat{S}_{L}(t) \neq \hat{S}_{p}(t)
\end{aligned}
$$

Untuk menguji hipotesis tersebut digunakan uji Log rakn yang dapat diperlihatkan melalui program R sebagai berikut

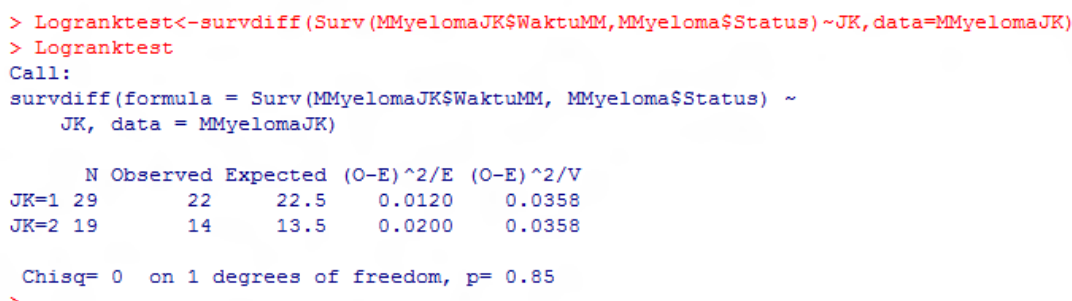

Dari hasil perhitungan tersebut, diperoleh nilai statistik uji yang mendekati 0 dengan nilai $p=0.85$. Karena $p=0.85>\alpha=0.05$, maka $H_{0}$ tidak ditolak. Artinya estimasi fungsi survival dari kelompok laki-laki dan kelompok perempuan masih dapat dikatakan sama. Jadi secara umum kita menyimpulkan bahwa kemampuan bertahan (survive) individu dari masing-masing kelompok sama.

Pembahasan hingga saat ini belum melibatkan variable-variabel yang dianggap dapat mempengaruhi waktu survival pasien Multiple Myeloma. Dalam data survival tentang penyakit Multiple Myeloma, banyak variable yang diamati. Tujuannya adalah mengetahui seberapa jauh pengaruh dari masing-masing variable tersebut terhadap kemampuan bertahan masing-masing individu penderita Multiple Myeloma. Untuk itu perlu dilakukan analisis dengan menggunakan model regresi. Setelah mendefinisikan semua variabel yang ada, berikut diperoleh output program $R$ yang berisi data survival beserta variable-variabel penjelasnya. 
Hasil analisis regresi survival dengan menggunakan program $R$ diperlihatkan dalam keluaran sebagai berikut yang masing-masing menggunakan distribusi eksponensial dan weibull.

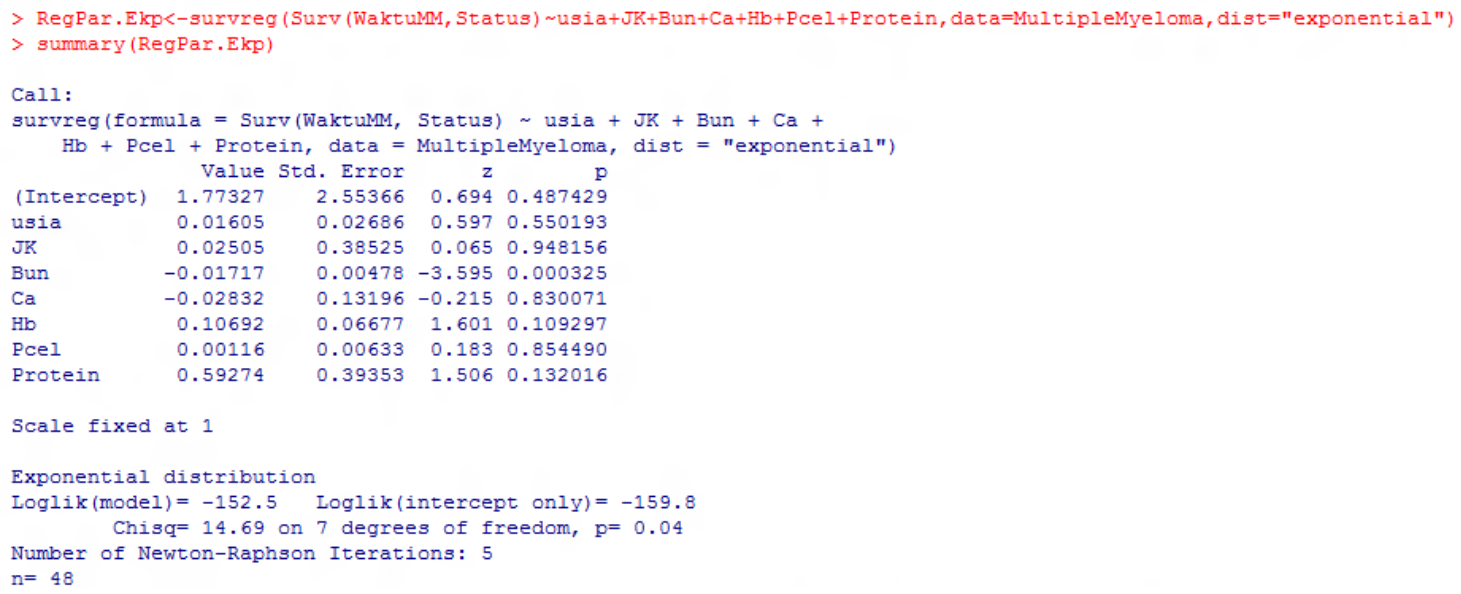




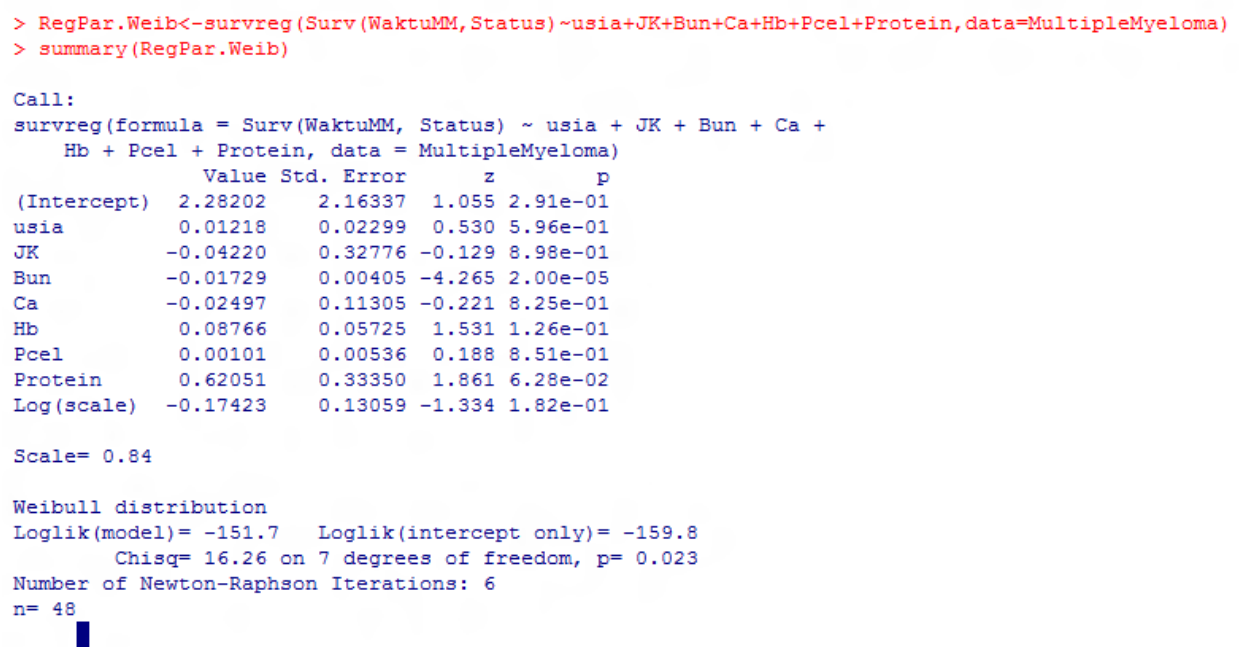

Terdapat dua model yang digunakan dalam analisis regresi survival di atas, yaitu dengan menggunakan distribusi eksponensial dan distribusi weibull. Dengan menggunakan distribusi eksponensial diperoleh nilai estimasi parameternya sebagai berikut: 0.01605 , $0.02505,-0.01717,-0.02832,0.10692,0.00101,0.00116$, dan 0.59274 berturut-turut untuk Variable usia, JK, Bun, Ca, Hb, Pcel, dan Protein. Sedangkan untuk intercept diperoleh nilai 1.77327. Dari semua variable ternyata hanya ada satu variable yan memberikan pengaruh yang signifikan pada taraf $\alpha=5 \%$. Variabel yang memberikan pengaruh yang signifikan tersebut adalah variable Bun, yaitu kadar blood urea nitrogen dengan nilai koefisiennya 0.01717 Nilai parameter yang bernilai negative tersebut menjelaskan bahwa Variabel Bun memberikan efek yang negative terhadap waktu survival, artinya semakin tinggi kadar blood urea nitrogen maka waktu survival individu penderita Multiple Myeloma akan semakin rendah dengan kata lain individu akan semakin cepat meninggal.

Dengan menggunakan distribusi weibull diperoleh nilai estimasi parameternya sebagai berikut: $0.01218,-0.04220,-0.01729,-0.02497,0.08766,0.00101$, dan 0.62051 berturut-turut untuk Variable usia, JK, Bun, Ca, Hb, Pcel, dan Protein. Sedangkan untuk intercept diperoleh nilai 1.77327. Tidak jauh berbeda dengan model yang menggunakan distribusi eksponensial, pada model ini juga diperoleh kesimpulan bahwa variable yang memberikan pengaruh yang signifikan pada taraf $\alpha=5 \%$ adalah variable Bun. Tetapi untuk taraf signifikansi $\alpha=7 \%$, terdapat satu variable lagi yang memberikan pengaruh yag signifikan, yaitu variable Protein dengan koefisien 0.62051. Artinya Variabel protein berbanding lurus dengan waktu survival penderita penyakit Multiple Myeloma, dengan kata lain adanya protein Bence Jones di dalam air seni lebih dimungkinkan ditemukan pada individu penderita Multiple Myeloma yang lebih survive. 


\section{KESIMPULAN}

Kesimpulan yang diperoleh dari pembahasan ini adalah bahwa Jenis kelamin tidak mempengaruhi kemampuan bertahan individu penderita penyakit Multiple Myeloma. Dari variable-variabel yang dipelajari ternyata yang memberikan pengaruh yang paling signifikan adalah variable Bun yaitu kadar blood urea nitrogen baik menggunakan distribusi eksponensial maupun weibull. Namun dengan menggunakan distribusi weibull, adanya Protein Bence Jones di dalam air seni juga memberikan pengaruh yang cukup nyata.

\section{DAFTAR PUSTAKA}

1. E. Kenah, Nonparametric Survival Analysis of Epidemic Data, Working Paper, Department of Biostatistics, University of Washington, Seattle, USA, 2011

2. Cox, D. R. and Oakes, D. O. (1984). Analysis of survival data, Chapman \& Hall Ltd.

3. Klein, J. and Moeschberger, M. (2003). Survival analysis: techniques for censored and truncated data, Statistics for biology and health, Springer.

4. Lawless, J. (2003). Statistical models and methods for lifetime data, Wiley series in probability and statistics, Wiley-Interscience 